\title{
Whey Protein Isolate based Biodegradable Food Packaging Film as affected by Protein to Glycerol Ratio, pH and Sonication Amplitude
}

\author{
M. Shingala Abhishaben ${ }^{1 *}$, V.K. Chandegara ${ }^{2}$, Bhukya Jithender ${ }^{3}$ and \\ M. Singala Pankajkumar ${ }^{4}$
}

${ }^{1}$ Department of Processing and Food Engineering, College of Agricultural Engineering \&

Technology, Junagadh Agricultural University, Junagadh, India

${ }^{3}$ Department of Agricultural Processing \& Structure, Central Institute of Agricultural

Engineering, Bhopal-462038 (Madhya Pradesh), India

${ }^{4}$ Department of Chemistry, Saurashtra University, Rajkot-360005, India

*Corresponding author:

\section{Keywords}

Biodegradable,

Whey protein

isolate, Glycerol, food Packaging film

Article Info

Accepted:

10 February 2019

Available Online:

10 March 2019

\section{A B S T R A C T}

The present study aimed at developing and characterizing biodegradable films produced by casting technique using whey protein isolate. Whey proteins are a by-product from the cheese industry. Packaging film was prepared by dissolving WPI and glycerol in distilled water with continuous stirring to obtain a film-forming solution. The $\mathrm{pH}$ of the film forming solution was adjusted and heated to $90 \pm 2{ }^{\circ} \mathrm{C}$ for $30 \mathrm{~min}$ in a water bath. The filtered WPI solution was subjected to ultrasonication at different levels according design of experiment. The film forming solution casted on petri dishes and dried at $35 \pm 1{ }^{\circ} \mathrm{C}$ for $24 \mathrm{~h}$ in a hot air dryer and film was peeled and tested at room temperature $\left(24 \pm 1^{0} \mathrm{C}\right)$. The effect of three independent variables viz.,WPI to Glycerol ratio $\left(\mathrm{X}_{1}\right), \mathrm{pH}$ of solution $\left(\mathrm{X}_{2}\right)$, Sonication Amplitude $\left(\mathrm{X}_{3}\right)$ were studied and these variables coded as respectively. Response variables viz., thickness, weight gain, moisture content, appearance, transparency and density were measured for optimization of the process. Response Surface Methodology (RSM) was used for designing the experiment. The results showed that the biodegradable packaging film should be prepared by incorporation WPI to Gly ratio as 1.5 with maintain $\mathrm{pH}$ of 7.08 at 100 sonication amplitude to get film thickness 0 f 0.275698 $\mathrm{mm}$, density $1.85064 \mathrm{gm} / \mathrm{cm}^{3}$, moisture content $27.7102 \%$, transparency 2.32937 . Using RSM graph, we concluded the effect of processing parameter on the characteristics of the biodegradable film.

\section{Introduction}

The purpose of the food packaging is to preserve and protect the food product throughout the manufacturing, transport, storage and consumption chain. Good packaging also guarantees the health and safety of consumers. Generally after using food product the packaging material is thrown which is dangerous to the environment. 
Around the world, people are facing grave issues of plastic packaging waste as conventional plastics take hundreds of years to decompose. To tackle this issue several countries have banned use of plastic products and are promoting use of eco-friendly biodegradable food packaging materials. India had a growing role in the world towards mitigating climate change.A biodegradable plastic is the material which falling apart into very small fragments due to the action of naturally occurring micro-organisms such as bacteria, fungi and algae. For the degradation oxygen and water is required and the plastic must be derived from biopolymer rather than petro-polymers. Biopolymers are obtained via polymerization of biobased raw materials through engineered industrial processes. Polyesters, protein, polysaccharide, polyphenol and lipid are the example of biopolymer which can be used to develop biodegradable packaging material.

Protein denatured by heat, acid, alkali and solvent in order to form the more extended structures which are required for film formation (Bourtoom, 2008). The cross linking of proteins by means of Chemical, Enzymatic, Physical treatment. Denaturation of proteins begins at $40^{\circ} \mathrm{C}$ and $\beta$-LG does not denature until $78^{\circ} \mathrm{C} .95 \%$ of protein denatures irreversibly at $85^{\circ} \mathrm{C}$ and gelation occurs above this temperature (Kilara and Vaghela 2004).Texture of WPI gels was affected by $\mathrm{pH}$ of solution (Suzana et al., 1997). Theeranun and Krochta (2010) found that WPs are globular and heat labile in nature.Plenty of studies regarding protein-based films have been produced especially about soy protein, whey protein, corn protein (zein), gluten and rice protein. Whey proteins are a by-product from the cheese industry. There are two type of whey protein. Whey protein isolates (WPI) and Whey protein concentrate(WPC).Many researchers have extensively studied preparation method for biodegradable film using whey protein as raw material and tested properties of film (Javier et al., 2007; Mahamadou et al., 2007; Majid 2009; Wang et al., 2010; Oscar et al., 2012; Kadam et al., 2013; Markus 2013; Zolfi et al., 2014). Galgano et al., (2015) found that biodegradable packaging give shelf-life prolongation of fruits and vegetables. Javier et al., (2007) formed film using WPI and glycerol and found that Films with Gly were much more flexible and less brittle. 5\% WPI with 3.6:1WPI: Gly ratio showed the best result for thickness and water vapor permeability. (Mahamadou et al., 2007). Water vapor permeability of hydrophilic protein films is affected by film thickness (Roy et al., 2000). The glycerol is important in the structure development of film (Igor et al., 2007). Looking to the problems of plastics packaging, a research investigation planned for the preparation of biofilm by using whey protein isolates with objective to standardize the process parameters for development of WPI packaging film and characterize the effects of WPI:Gly ratio, $\mathrm{pH}$ of solution and sonication on physical properties of film.

\section{Materials and Methods}

Materials required for film were Whey protein isolates (BulkAmino, Advance Nutratech, New Delhi, India), Glycerol and all other chemicals in analytical grade were procured.

WPI and glycerol were dissolved in DD water with continuous stirring to obtain a filmforming solution. WPI to Gly ratio was taken as variable parameter like, $0.5,1$ and 1.5 . The $\mathrm{pH}$ of the film forming solution was adjusted with $2 \mathrm{~N} \mathrm{NaOH}$. The $\mathrm{pH}$ of solution was taken as variable in experiment like 7,8and 9. $\mathrm{pH}$ of solution was measured with the help of digital $\mathrm{pH}$ meter. Then, the solution was heated to 90 $\pm 2^{0} \mathrm{C}$ for $30 \mathrm{~min}$ in a water bath while being stirred continuously. After $30 \mathrm{~min}$ of heating, solution was rapidly cooled in an ice bath for 
10-15 min to avoid further denaturation. Then the solution was filtered through two layers of muslin cloth to remove any coagulation. The filtered WPI solution was subjected to ultrasonication at different levels according design of experiment. The film forming solution of $25 \mathrm{~g}$ was casted on petridishes and dried at $35 \pm 1^{0} \mathrm{C}$ for $24 \mathrm{~h}$ in a hot air dryer. Then dried film was kept in a $50 \% \pm 2 \% \mathrm{RH}$ in humidity chamber for at least $24 \mathrm{~h}$ for ease in film peeling and testing at room temperature $\left(24 \pm 1{ }^{0} \mathrm{C}\right)$. Peeling of film was done very carefully to prevent film from brake and crake.

The effect of three independent variables viz., WPI to Glycerol ratio, $\mathrm{pH}$ of solution, Sonication Amplitude was studied and these variables coded as $X_{1}, X_{2}$ and $X_{3}$ respectively. The levels of parameter values were carefully chosen based on the literature available. Response variables viz., Thickness, weight gain, Moisture content, appearance, odour, transparency, density, water absorption index and water solubility index, were measured for optimization of the process. Response Surface Methodology (RSM) was used for designing the experiment. A Central Composite Rotatable Design (CCRD) of 3 variables. Altogether 15 combinations were chosen according to a central composite rotatable design. The coded and uncoded variable values of the design are presented in Table 1.

\section{Film thickness}

Film thickness was measured with the help of digital Vernier Calipers (Mitutoyo corporation, Japan made, model- CD-12"), having a least count of $0.01 \mathrm{~mm}$ (Plate 3.3-B). Measurements were carried out at different film locations and the mean thickness value was used to calculate the permeability of the films. Film thicknesses are used to determine oxygen permeability (OP), water vapor transmission rate (WVTR) and mechanical film properties.

\section{Film weight}

Film weight was measured using a balance. Measurements were carried out and the mean weight value was used to calculate the weight of the films. It measured in grams.

\section{Film area}

Film area was measured using formula given below. For measuring area, we have to measure first diameter of film. $A=\pi r^{2}$ Where $\mathrm{A}=$ Film area and $\mathrm{r}=$ Radius of developed film in circular shape

\section{Film density}

Film density was measured using following formula. For measuring film density, first measure volume of film and weight of film

$\rho=\frac{\text { Weight of film(W) }}{\text { Volume of film(V) }}$

Where $\rho=$ Film density

$\mathrm{W}=$ weight of film

$\mathrm{V}=$ volume of film

\section{Moisture content}

Film moisture content was measured by oven drying method. Film samples were trimmed into small strips, dried in an oven at $100{ }^{\circ} \mathrm{C}$ for $24 \mathrm{~h}$ to a constant weight. The small strip has $1 \mathrm{gm}$ in weight. Samples were subsequently removed from the oven after 24 hrs. Final weights were recorded and moisture content calculated.

Moisture Content $=$ (Initial weight - final weight)/Initial weight $* 100 \%$

\section{Transparency of film}

The transparency of films was determined using a UV-1601 spectrophotometer 
(Shimadzu, Kyoto, Japan). The film samples were cut into rectangles and placed on the internal side of the spectrophotometer cell. The transmittance of films was determined at $600 \mathrm{~nm}$ as described by Han and Floros (1997). The transparency of the films was calculated as follows:

Transparency $=\log \frac{T 600}{x}$

Where, $\mathrm{T}_{600}$ is the transmittance at $600 \mathrm{~nm}$ and $\mathrm{x}$ is the film thickness ( $\mathrm{mm}$ ).

\section{Statistical analysis}

Response surface methodology (RSM) was applied for optimizing processing parameters for making biopolymer films from Whey Protein Isolates (WPI). CCRD design was used to statistically optimize the processing parameters and evaluate the main effects, interaction effects and quadratic effects of the processing parameters on WPI biopolymer film. A 3-factor, 3-level design was used to explore the quadratic response surfaces and for constructing second order polynomial models using Design Expert ${ }^{\circledR}$ (Version 8.0.2, Stat-Ease, Minneapolis, MN). The independent variables used for study are shown in Table 1. Levels of independent variables were selected on the basis of literature available and preliminary screening experiments. Analysis of variance (ANOVA) was conducted for fitting the model represented by following Equation to examine the statistical significance of model terms. Model analysis with respect to lack-of fit test and $\mathrm{R}^{2}$ (coefficient of determination) was done for determining adequacy of model. Response surfaces were generated and by using the same software, numerical optimization was done. The most commonly used model for optimization by using response surface methodology is of the form:

$\mathrm{Y}_{\mathrm{k}}=\sum_{\mathrm{i}=1}^{3} \mathrm{~b}_{\mathrm{k} 0} \mathrm{X}_{\mathrm{i}}+\sum_{\mathrm{i}=1}^{3} \mathrm{~b}_{\mathrm{kii}} \mathrm{X}_{\mathrm{i}}^{2}+\sum_{\mathrm{i}=1}^{3} \mathrm{~b}_{\mathrm{kij}} \mathrm{X}_{\mathrm{i}} \mathrm{X}_{\mathrm{j}}(\mathrm{k}$ $=0,1,2,3 \ldots)$
Where, $\mathrm{Y}_{\mathrm{k}}$ is the response, $\mathrm{b}_{\mathrm{k} 0}, \mathrm{~b}_{\mathrm{ki}}, \mathrm{b}_{\mathrm{kj}}$ are the constant, linear, quadratic and cross-product regression coefficients, respectively and $\mathrm{X}_{\mathrm{i}}{ }^{\text {' }}$ are the coded independent variables.

\section{Results and Discussion}

Physical, optical, biochemical properties of WPI packaging film are measured. The observation were analyzed using CCRD design (Response Surface Methodology) which statistically evaluate the main effects, interaction effects and quadratic effects of the different processing parameters on WPI biopolymer film with graphical presentation.

The effect of Whey Protein isolate to Glycerol ratio, $\mathrm{pH}$ and Sonification amplitude on different dependable parameters like moisture content, film thickness, density, moisture content and transparency for development of biodegradable film are discussed hereafter.

\section{Effect of WPI to Gly Ratio, pH and Sonication amplitude on film thickness}

Thickness of WPI based biopolymer film was measured by digital Verniar calipers in the unit of $\mathrm{mm}$. Results of film thickness are graphically presented in Figure 1. The thickness of film was recorded 0.25 to $0.3 \mathrm{~mm}$ for all the run. In all run, the effect of WPI to Gly Ratio, $\mathrm{pH}$ and Sonication amplitude on film thickness did not showed any significant difference.

It was observed that the thickness of edible films was highly influenced $(p<0.05)$ by the type and amount of biopolymer and plasticizer used in film preparation. Minimum film thickness was observed in run 13 (WPI:Gly ratio of $1,8 \mathrm{pH}$ and 100 Sonication amplitude) as $0.25 \mathrm{~mm}$, while maximum film thickness of $0.3 \mathrm{~mm}$ was recorded in run 11 (WPI:Gly ratio of $0.5,9 \mathrm{pH}$ and 100 Sonication amplitude) as presented in Table 2. As the concentration of 
plasticizer increased, the film thickness also increased. This might be due to increase proportion of plasticizer with $\mathrm{pH}$. Similar results were reported by Wagh (2014) for the thickness of glycerol-plasticized films ranged from 0.17 to $0.31 \mathrm{~mm}$. The actual effect of WPI to Gly Ratio, $\mathrm{pH}$ and Sonication amplitude on density of film was analysed with response surface curve and contour plot. It is evident from regression coefficient Table 2 , that the thickness of edible film was affected by negative effect of WPI to glycerol ratio $(\mathrm{p}<0.01)$ and positive linear effects of $\mathrm{pH}$ and Sonication amplitude. The other factors having significant effects were interaction of WPI to Gly ratio, $\mathrm{pH}$ and Sonication amplitude. The quadratic effect of WPI to Gly ratio was also found to influence the thickness of edible film. Quadratic relationship was established with the three process variables as per the following equation. Final equation in terms of coded factors

Thickness $=+0.27+7.071 * \mathrm{X}_{1}+3.536 * \mathrm{X}_{2}$ $3.536 * \mathrm{X}_{3}-3.536 * \mathrm{X}_{1} * \mathrm{X}_{2}+3.536 * \mathrm{X}_{1} *$ $\mathrm{X}_{3}+0.012 * \mathrm{X}_{2} * \mathrm{X}_{3}+5.370 * \mathrm{X}_{1}{ }^{2}+2.870 * \mathrm{X}_{2}{ }^{2}$ $2.130 * \mathrm{X}_{3} 2$

Final equation in terms of actual factors

Thickness $=+0.68262+6.53451 *$ WPI to Gly ratio- $0.071533 * \mathrm{pH}$ of solution-3.77589* Sonication amplitude-7.07107 * WPI to Gly ratio $* \mathrm{pH}$ of solution+2.82843* WPI to Gly ratio $*$ Sonication amplitude $+4.82843 * \mathrm{pH}$ of solution * Sonication amplitude+0.021481* WPI to Gly ratio ${ }^{2}+2.87037 * \mathrm{pH}$ of solution ${ }^{2}$ $3.40741 *$ Sonication amplitude 2

From the response surface curve and the contour map of interaction, it was observed that thickness was found to be increased with decreased in WPI:Gly ratio. Density of film is inversely influenced by $\mathrm{pH}$ level of solution. Sonication improves the distribution of WPI particles in film matrix which can potentially become effective packaging materials.
Thickness was found to decrease with increase in sonication amplitude and WPI to glycerol ratio and also the thickness was found to be decreased with increase in sonication amplitude and $\mathrm{pH}$ level of solution.

\section{Effect of WPI to Gly Ratio, pH and Sonication amplitude on density of film}

The brittleness of film is adjudged by the density of film. Density of WPI based biopolymer film was determined by standard formula and results were described in Table 2 . The combine effect of WPI:Gly ratio, $\mathrm{pH}$ and Sonication amplitude on density of film was graphically presented in Figure 2, 3 and 4.

The density of biodegradable film is related with weight and thickness of film. The maximum density was found $2.62 \mathrm{~kg} / \mathrm{m}^{3}$ in the run 7(WPI:Gly ratio of $0.5,7 \mathrm{pH}$ and 50 Sonication amplitude) and minimum density of $1.48 \mathrm{~kg} / \mathrm{m}^{3}$ recorded in run 10 (WPI:Gly ratio of $1,8 \mathrm{pH}$ and 50 Sonication amplitude) as presented in Table 2. As the WPI:Gly ratio and $\mathrm{pH}$ of solution increased then the density of film was decreased. The proportion of glycerol is directly proportional to the density of the film. Similar results were found by Singh et al., (2015) for the density of chitosan based glycerol-plasticized films ranged from 1.34 to $1.44 \mathrm{~kg} / \mathrm{m}^{3}$. The actual effect of WPI to Gly Ratio, $\mathrm{pH}$ and Sonication amplitude on density of film was analysed with response surface curve and contour plot.

It is evident from regression coefficient Table 2 , that the Density of edible film was affected by negative linear effect of WPI to glycerol ratio $(\mathrm{p}<0.01)$ and positive linear effects of $\mathrm{pH}$ and Sonication amplitude. The other factors having significant effects were interaction of WPI to Gly ratio, $\mathrm{pH}$ and Sonication amplitude. The quadratic effect of WPI to Gly ratio was also found to influence the density of edible film. 
As per the response surface model, the density of film was found to have quadratic relationship with of WPI to Gly Ratio, $\mathrm{pH}$ and Sonication amplitude. The Model $\mathrm{F}$ value of 4.99 implies that the model is significant $(\mathrm{P}<$ 0.05). Regression coefficient $\left(\mathrm{R}^{2}\right)$ and Adjusted $\mathrm{R}^{2}$ values of the model are 0.8997 and 0.7193 respectively.

The adequate precision value of 8.497 indicates that the model can be used to navigate the design space as it is greater than 4.0. Quadratic relationship was established with the three process variables as per the following equation. Final equation in terms of coded factors,

Density $=1.86-0.30 * \mathrm{X}_{1}+0.042 * \mathrm{X}_{2}+$ $0.11 * \mathrm{X}_{3}+0.19 * \mathrm{X}_{1} * \mathrm{X}_{2}+0.32 * \mathrm{X}_{1} * \mathrm{X}_{3}-$ $0.036 * \mathrm{X}_{3} * \mathrm{X}_{2}+0.19 * \mathrm{X}_{1}{ }^{2}-0.095 * \mathrm{X}_{2}^{2}-0.06$ $* \mathrm{X}_{3}{ }^{2}$

Final equation in terms of actual factors

Density $=-0.031795-6.98340 *$ WPI:Gly ratio+1.29537 * pH of solution+4.59283E003* Sonication Amplitude +0.37213 * WPI:Gly ratio * $\mathrm{pH}$ of solution+0.025394* WPI:Gly ratio *Sonication Amplitude1.42082E-003* $\mathrm{pH}$ of sol2tion * Sonication Amplitude+0.75037* WPI:Gly ratio ${ }^{2}$ $0.094907 * \mathrm{pH}$ of solution ${ }^{2}-9.58519 \mathrm{E}-005 *$ Sonication Amplitude ${ }^{2}$

From the response surface curve and contour plot for density of film it was observed that density was found to be increased with decreased in WPI:Gly ratio. Density of film is inversely influenced by $\mathrm{pH}$ level of solution. The density was found to decrease with increase in sonication amplitude and WPI to glycerol ratio and density was decreased with increase in sonication amplitude and $\mathrm{pH}$ level of solution.
Effect of WPI to Gly Ratio, pH and Sonication amplitude on moisture content of film

Packaging films should maintain moisture levels within the packaged product. Therefore, the knowledge of moisture content and total soluble matter of the films is very important for food packaging applications (Leceta et al., 2013). The amount of water present in films provide an indication of the hydrophobicity of the films, hence, the hydrophilic films have higher moisture content (Bourbon et al., 2011).

The maximum moisture content was found 39.2 in the run 8 (WPI:Gly ratio of $1,9 \mathrm{pH}$ and 75 Sonication amplitude) and minimum moisture content of 17.25 recorded in run 10 (WPI:Gly ratio of $1.5,8 \mathrm{pH}$ and 75 Sonication amplitude) as presented in Table 2. As the WPI:Gly ratio increased then the moisture content of film was decreased and $\mathrm{pH}$ level increased then moisture content also increased. The proportion of glycerol is directly proportional to the density of the film. The similar result explained by Singh et al., (2015) that the moisture content of chitosan based film was varies between 12 to $19 \%$ moisture content. The actual effect of WPI to Gly Ratio, $\mathrm{pH}$ and Sonication amplitude on density of film was analysed with response surface curve and contour plot. In the present study, it was found to fit with the three variables as per quadratic relationship. The best model equation for moisture was,

M.C $=+33.53-4.05 * \mathrm{X}_{1}+1.12 * \mathrm{X}_{2}-1.01 * \mathrm{X}_{3^{-}}$ $2.38 * \mathrm{X}_{1} * \mathrm{X}_{2}+1.62 * \mathrm{X}_{1} * \mathrm{X}_{3}-0.067 * \mathrm{X}_{2} * \mathrm{X}_{3}-$ $5.39 * \mathrm{X}_{1}{ }^{2}+1.93 * \mathrm{X}_{2}{ }^{2}+0.15 * \mathrm{X}_{3}{ }^{2}$

M.C $=+108.99344+63.31242 *$ WPI:Gly ratio$24.78102 * \mathrm{pH}$ of solution- $0.18481 *$ Sonication Amplitude-4.75525* WPI:Gly ratio * $\mathrm{pH}$ of solution+0.12954* WPI:Gly ratio * Sonication Amplitude $\quad-2.66887 \mathrm{E}-003^{*} \mathrm{pH}$ of 
solution*SonicationAmplitude-

WPI:Gly ratio $^{2}+1.92880 * \mathrm{pH} \quad$ of solution $^{2}+2.42074 \mathrm{E}-004 *$ Sonication Amplitude 2

The effect of glycerol level (quadratic) on moisture was significant $(\mathrm{p}<0.05)$. Regression coefficient $\left(\mathrm{R}^{2}\right)$ value $(0.9987)$ indicated that $1.03 \%$ of the total variation was not explained by the present model. The Model F-value was significant and there is only a $0.01 \%$ chance that it could occur due to noise. With the increase in whey protein isolate level, moisture content decreased and thereafter increased after reaching to a certain minima and reverse was true with glycerol level. Fundo et al., (2008) observed that high chitosan/glycerol concentration solutions led to films with significantly $(\mathrm{p}<0.05)$ higher water content. This can be related with higher molecular entanglement and viscosity, which lead to higher retention of water molecules during drying of the films. Sobral et al., (2001) observed that the increase in the plasticizer concentration increases the moisture content of the film because of its high hygroscopic character, which also contributes to the reduction of the forces between the adjacent macromolecules.

From the response surface curve and contour plot for moisture content of film it was observed that moisture content was found to increase with increase in WPI:Gly ratio and $\mathrm{pH}$ up to certain point of maxima and then its start to decrease with increasing level of relative variables.

The moisture content was found to increase with increase in sonication amplitude and WPI to glycerol ratio up to reaching maximum at 0.7 WPI:Gly ratio and 70 sonication amplitude after that its start to decrease with increasing the relative variables. The moisture content was found to decrease with increase in sonication amplitude and $\mathrm{pH}$ level of solution up to reaching minimum value and then start increasing with increasing of relative variables.

Effect of WPI to Gly Ratio, pH and Sonication amplitude on transparency of film

Transmittance indicates about light barrier properties of WPI films. This property is important to prevent lipid oxidation induced by UV light in food system (Ramos et al., 2013). Hence, it is an important parameter to evaluate the efficacy of packaging films for foods (Leceta et al., 2013). The maximum transparency was found 2.33 in the run 8 (WPI:Gly ratio of $1.5,7 \mathrm{pH}$ and 100 Sonication amplitude) and minimum transparency of 2.16 recorded in run 1 (WPI:Gly ratio of $1.5,9 \mathrm{pH}$ and 50 Sonication amplitude) as presented in Table 2. As the $\mathrm{pH}$ level increased, transparency start to decrease. While Sonication amplitude increase then transparency also transparency. Wpi to glycerol ratio is not significantly affect the transparency. Similar results were found by Kadam et al., (2013) for the transparency of WPI based glycerol-plasticized films and explained that Sonication process gives the transparency to the film. The actual effect of WPI to Gly Ratio, $\mathrm{pH}$ and Sonication amplitude on transparency of film was analysed with response surface curve and contour plot. Transmittance was found to have quadratic relationship with the three process variables as per the following equation,

Transparency $=+2.27-0.021 * \mathrm{~A}-0.018 *$ $\mathrm{B}+7.071 \mathrm{E}-003 * \mathrm{C}-0.035^{*} \mathrm{~A} * \mathrm{~B}+0.025 * \mathrm{~A} *$ $\mathrm{C}-0.029 * \mathrm{~B} * \mathrm{C}+6.111 \mathrm{E}-003 * \mathrm{~A}^{2}-1.389 \mathrm{E}-$ $003 * \mathrm{~B}^{2}-0.034 * \mathrm{C}^{2}$

Transparency $=+0.95837+0.32661 *$ WPI:Gly ratio $+0.16154 * \mathrm{pH}$ of solution $+0.015619 *$ Sonication Amplitude- 0.070858 *WPI:Glyratio*pHofsolution+1.98579E-003* WPI:Glyratio* SonicationAmplitude- 
1.14853E-003* $\mathrm{pH}$ of solution* Sonication Amplitude $+0.024444 *$ WPI:Gly ratio 2 $1.38889 \mathrm{E}-003 * \mathrm{pH}$ of solution $^{2}-5.42222 \mathrm{E}-$ $005 *$ SonicationAmplitude 2

This shows that WPI to gly ratio (quadratic effect), $\mathrm{pH}$ (quadratic) and sonication amplitude (quadratic effect) significantly $(\mathrm{p}<0.05)$ affected transmittance of films. Furthermore, a very high degree of precision and a good deal of the reliability of the conducted experiment was indicated by a low value of the coefficient of variation $(\mathrm{CV}=0.36$ $\%)$. The R2 value (0.9879), being a measure of the goodness of fit of the model, indicated that $98.79 \%$ of the total variation was explained by the model. Transmittance decreased with the level of WPI however; it increased with glycerol. Yan et al., (2012) documented that the films containing $35 \%$ glycerol had the highest light transmittance rate, whereas lowest with $30 \%$ glycerol level.

Table.1 Experimental design Summary (by RSM)

\begin{tabular}{|l|c|c|c|c|}
\hline Variables & Coded $\mathbf{X}_{\mathbf{i}}$ & \multicolumn{4}{|c|}{ Coded levels } \\
\cline { 3 - 5 } & & $\mathbf{- 1}$ & $\mathbf{0}$ & $\mathbf{+ 1}$ \\
\hline WPI:Gly ratio & $\mathrm{X}_{1}$ & 0.5 & 1 & 1.5 \\
\hline pH of WPI solution & $\mathrm{X}_{2}$ & 7 & 8 & 9 \\
\hline Sonication Amplitude & $\mathrm{X}_{3}$ & 50 & 75 & 100 \\
\hline
\end{tabular}

Table.2 Effect of process variables and values of experimental responses for developed WPI based biodegradable film

\begin{tabular}{|c|c|c|c|c|c|c|c|}
\hline \multirow[t]{2}{*}{ Run } & \multicolumn{3}{|l|}{ Variable } & \multicolumn{4}{|l|}{ Responses } \\
\hline & $\begin{array}{l}\text { WPI:Gly } \\
\text { X }_{1}\end{array}$ & $\begin{array}{l}\mathbf{p H} \\
\mathbf{X}_{2}\end{array}$ & $\begin{array}{l}\text { Soni. } \\
\text { Amplitude } \\
\mathbf{X}_{3}\end{array}$ & $\begin{array}{l}\text { Thick ness } \\
(\mathbf{m m})\end{array}$ & $\begin{array}{l}\text { Density } \\
\left(\mathrm{g} / \mathrm{cm}^{3}\right)\end{array}$ & $\begin{array}{l}\text { Moisture } \\
\text { content }(\%)\end{array}$ & Transparency \\
\hline 1 & 1.5 & 9 & 50 & 0.29 & 1.54 & 24.15 & 2.16 \\
\hline 2 & 1.5 & 8 & 75 & 0.28 & 1.7 & 17.25 & 2.26 \\
\hline 3 & 1 & 8 & 75 & 0.28 & 1.94 & 33.44 & 2.27 \\
\hline 4 & 1 & 8 & 75 & 0.28 & 1.94 & 33.44 & 2.27 \\
\hline 5 & 1 & 8 & 75 & 0.28 & 1.94 & 33.44 & 2.27 \\
\hline 6 & 1 & 7 & 75 & 0.26 & 1.5 & 36.02 & 2.3 \\
\hline 7 & 0.5 & 7 & 50 & 0.3 & 2.62 & 33.11 & 2.23 \\
\hline 8 & 1.5 & 7 & 100 & 0.29 & 1.93 & 27.88 & 2.33 \\
\hline 9 & 1 & 9 & 75 & 0.27 & 1.62 & 39.2 & 2.25 \\
\hline 10 & 1 & 8 & 50 & 0.26 & 1.48 & 35.48 & 2.2 \\
\hline 11 & 0.5 & 9 & 100 & 0.3 & 1.91 & 34.86 & 2.23 \\
\hline 12 & 1 & 8 & 75 & 0.28 & 1.75 & 33.44 & 2.27 \\
\hline 13 & 1 & 8 & 100 & 0.25 & 1.78 & 32.63 & 2.22 \\
\hline 14 & 0.5 & 8 & 75 & 0.26 & 2.55 & 28.71 & 2.32 \\
\hline 15 & 1 & 8 & 75 & 0.28 & 1.94 & 33.44 & 2.27 \\
\hline
\end{tabular}

$\mathrm{X}_{1}$ is coded independent variable for WPI:Gly ratio level, $\mathrm{X}_{2}$ is coded independent variable for $\mathrm{pH}$ level, $\mathrm{X}_{3}$ is coded independent variable for Sonication amplitude. 
Fig.1 Response surface plot for thickness. A. Effect of WPI:Gly ratio and pH of solution on thickness of film. B. Effect of WPI:Gly ratio and sonication amplitude of solution on thickness of film. C. Effect of sonication and $\mathrm{pH}$ of solution on thickness of film

A.

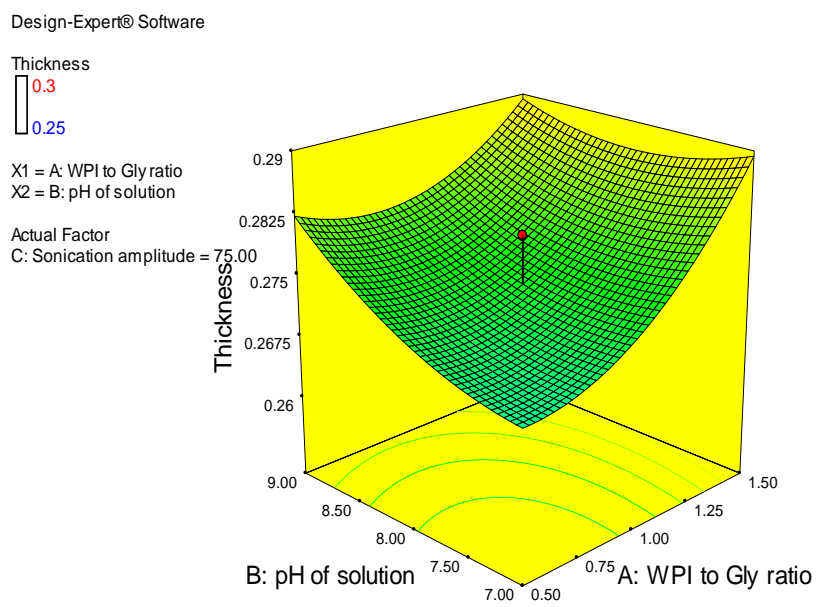

B.

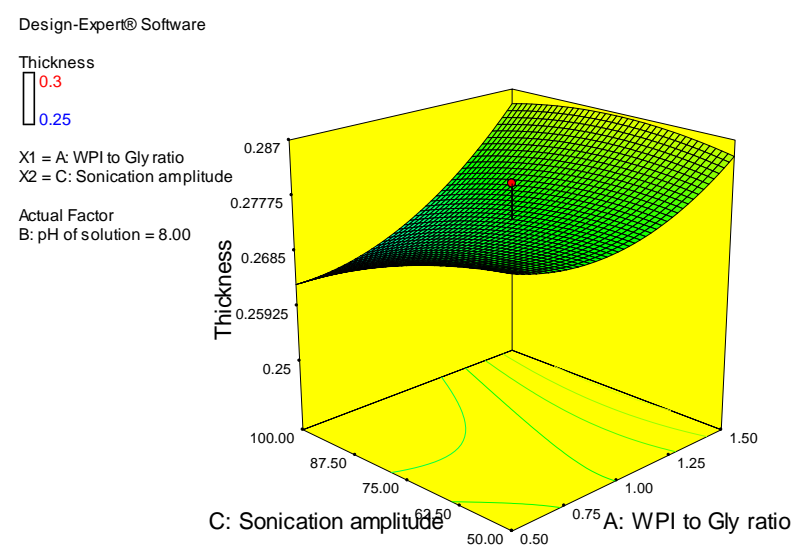

C.

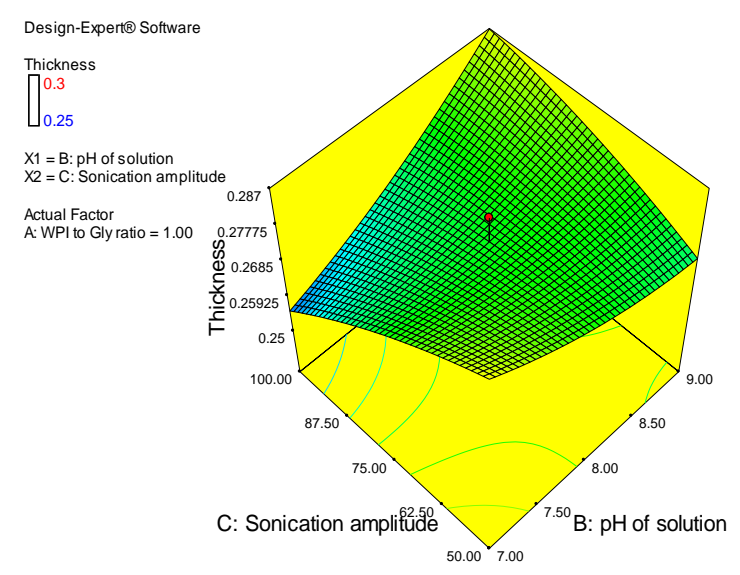


Fig.2 Response surface plot for Density. A. Effect of WPI:Gly ratio and $\mathrm{pH}$ of solution on density of film. B. Effect of WPI:Gly ratio and sonication amplitude of solution on density of film. C. Effect of sonication and $\mathrm{pH}$ of solution on density of film

A

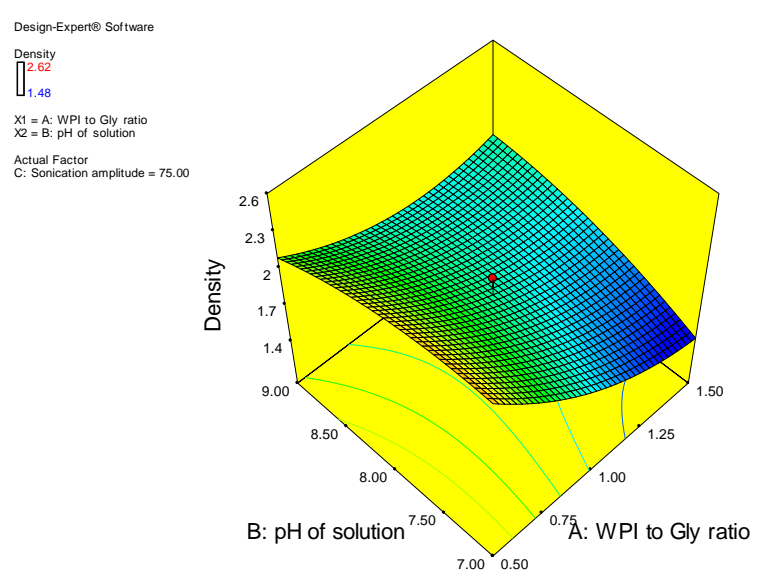

B.
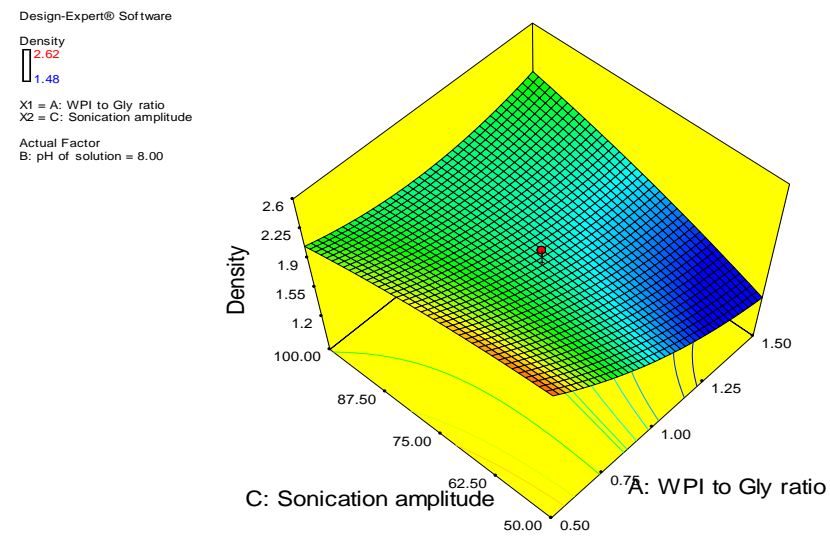

C.

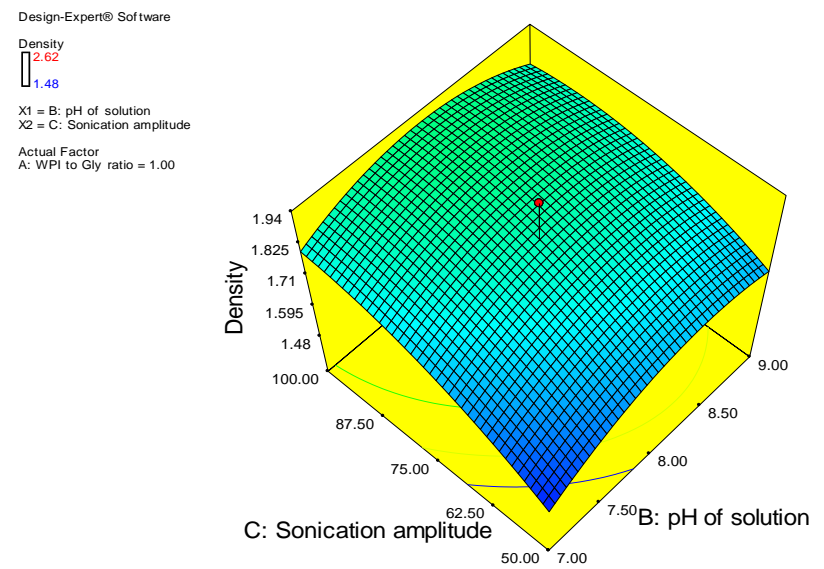


Fig.3 Response surface plot for Moisture Content. A. Effect of WPI:Gly ratio and pH of solution on Moisture Content of film. B. Effect of WPI:Gly ratio and sonication amplitude of solution on Moisture Content of film. C. Effect of sonication and $\mathrm{pH}$ of solution on Moisture Content of film

A.

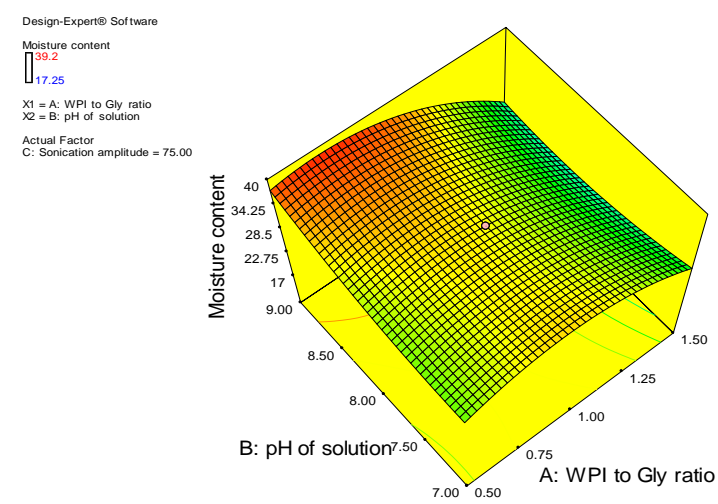

B.
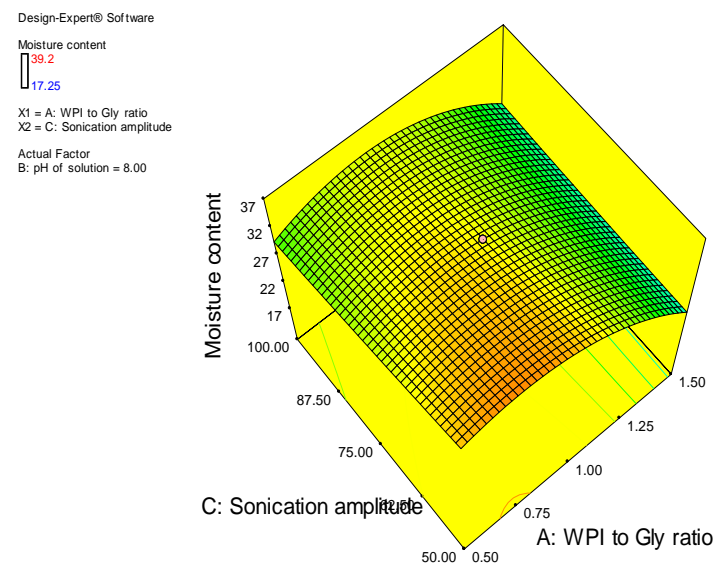

C.

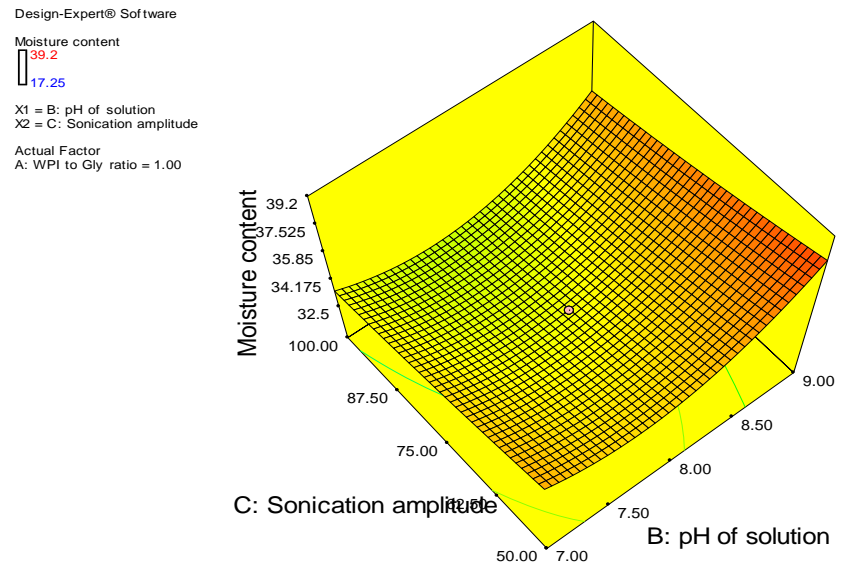


Fig.4 Response surface plot for transparency. A. Effect of WPI:Gly ratio and $\mathrm{pH}$ of solution on transparency of film. B. Effect of WPI:Gly ratio and sonication amplitude of solution on transparency of film. C. Effect of sonication and $\mathrm{pH}$ of solution on transparency of film

A.

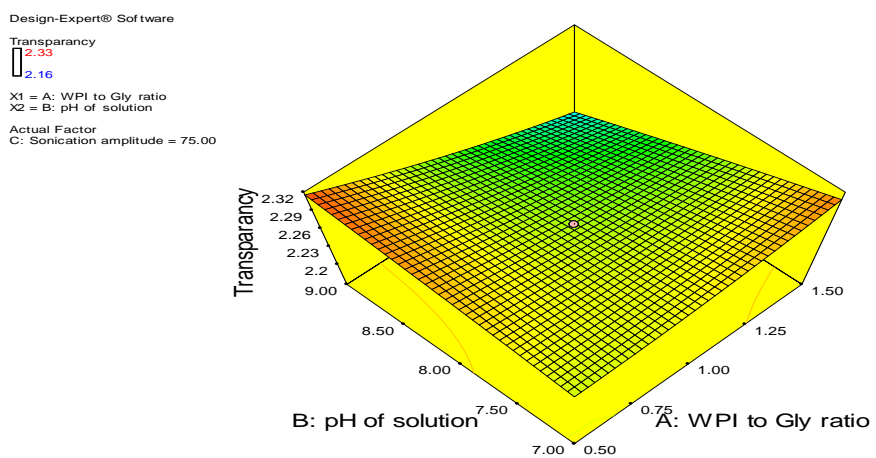

B.
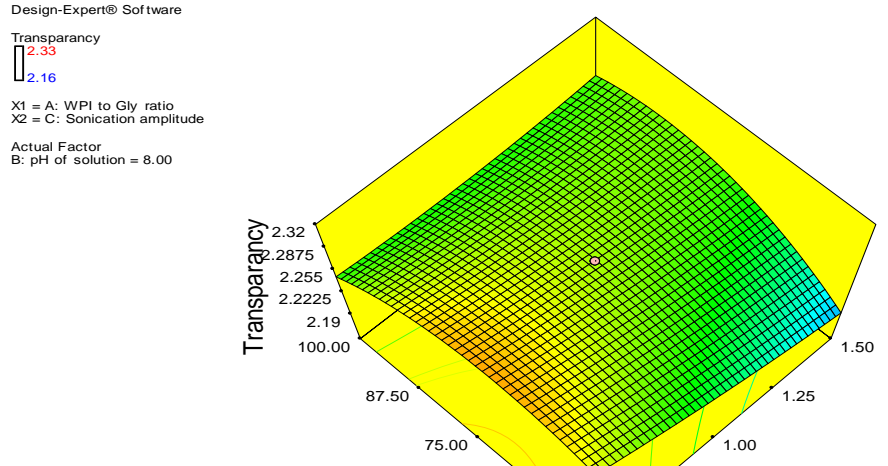

C: Sonication amplitude

C.
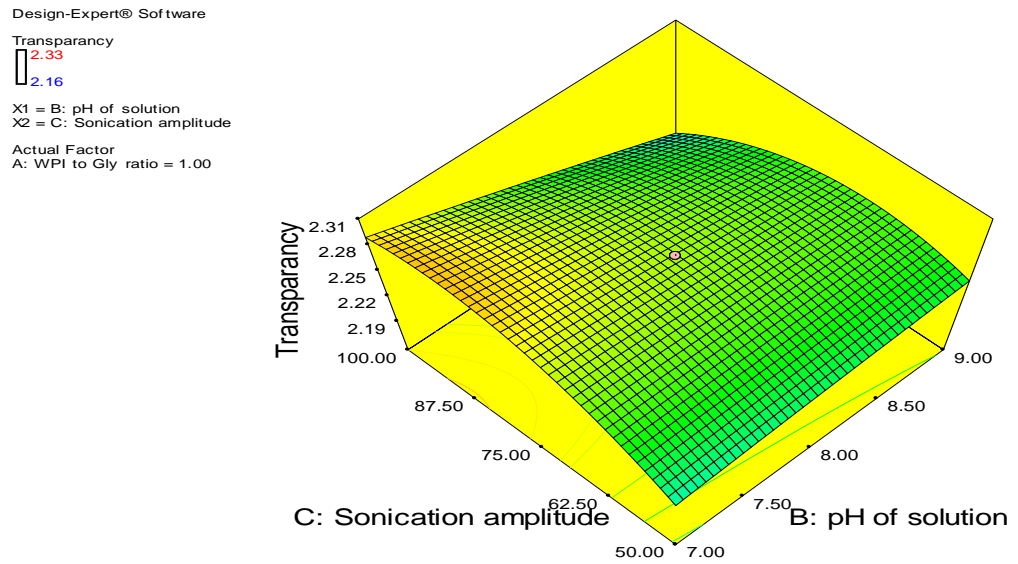

From the response surface curve and contour increase in WPI:Gly ratio and $\mathrm{pH}$. The plot for transparency of film, it was observed transparency was found to first increase and that transparency was found to decrease with after rich maxima its start to decrease with 
increase in sonication amplitude and WPI to glycerol ratio. Sonication improved distribution of WPI particles in film matrix; that's why the transparency of film also got better result.

In conclusion, in this study, biodegradable films were developed based on WPI using the casting method. The results showed that the properties of these films were greatly influenced by WPI to gly ratio, $\mathrm{pH}$ of solution and sonication amplitude. Physical and biochemical properties of Whey protein isolate (WPI) powder were $\mathrm{pH} 6.8$, protein content $89.5 \%$. All the films were flexible and homogeneous without surface cracks and pores. The presence of whey protein isolate in biodegradable film imparted yellow color. The appearance of the film facing the mould base was shiny than the surface exposed to air during drying. All the films were easy to peel off from the mould except WPI film at 0.5 WPI to Gly ratio, which might be due to its lower thickness and higher plasticizer ratio. Film thickness of whey protein isolate biopolymer film was ranged between 0.25 to $0.3 \mathrm{~mm}$. The minimum film thickness was observed in run 13 (WPI:Gly ratio of $1,8 \mathrm{pH}$ and 100 Sonication amplitude) as $0.25 \mathrm{~mm}$, while maximum film thickness of $0.3 \mathrm{~mm}$ was recorded in run 11 (WPI:Gly ratio of 0.5 , $9 \mathrm{pH}$ and 100 Sonication amplitude). The density of whey protein isolate biopolymer film was ranged between 1.48 to 2.62 $\mathrm{kg} / \mathrm{m}^{3}$.The maximum density was found 2.62 $\mathrm{kg} / \mathrm{m}^{3}$ in the run 7 (WPI:Gly ratio of $0.5,7 \mathrm{pH}$ and 50 Sonication amplitude) and minimum density of $1.48 \mathrm{~kg} / \mathrm{m}^{3}$ recorded in run 10 (WPI:Gly ratio of $1,8 \mathrm{pH}$ and 50 Sonication amplitude). The moisture content of whey protein isolate biopolymer film was ranged between 17.25 to 39.2. The maximum moisture content was found 39.2 in the run 8 (WPI:Gly ratio of $1,9 \mathrm{pH}$ and 75 Sonication amplitude) and minimum moisture content of 17.25 recorded in run 10 (WPI:Gly ratio of
$1.5,8 \mathrm{pH}$ and 75 Sonication amplitude). The transparency of whey protein isolate biopolymer film was ranged between 2.16 to 2.33. The maximum transparency was found 2.33 in the run 8 (WPI:Gly ratio of $1.5,7 \mathrm{pH}$ and 100 Sonication amplitude) and minimum transparency of 2.16 recorded in run 1(WPI:Gly ratio of $1.5,9 \mathrm{pH}$ and 50 Sonication amplitude). Response surface methodology using CCRD design was found to be an effective technique to optimize the process development of WPI based packaging film as a function of 1.5 WPI to Gly ratio, $7.08 \mathrm{pH}$ level and 100 sonication amplitude. From the response surface plots the three independent variables were found to significantly influence all the response variables either independently or interactively. It was concluded from the analysis that the biodegradable packaging film should be prepared by incorporation WPI to Gly ratio as 1.5 with maintain $\mathrm{pH}$ of 7.08 at 100 sonication amplitude to get film thickness of $0.275 \mathrm{~mm}$, density $1.850 \mathrm{gm} / \mathrm{cm}^{3}$, moisture content $27.710 \%$, transparency 2.329. In Food packaging materials, WPI film proven good potential towards improving quality and enhancing safety of food materials as well as reducing the plastic pollution.

\section{Acknowledgement}

I am obliged to Prof. D. M. Vyas, Professor and Head, PFE Department, CAET, JAU, Junagadh for his valuable guidance, Dr. P. J. Rathod, Assistant Professor, Department of Biochemistry, JAU, Junagadh. And Mr. Punit R. Bhatt, RA, Department of Veterinary Pharmacology and Toxicology, College of Veterinary Science and Animal Husbandry.

\section{References}

Anderson, R. A., Conway, H. F. and Griffin, J. E. L. 1969. Gelatinization of corn grits by roll and extrusion cooking. 
Cereal Science Today, 14: 4-7.

Bourbon A. I., Pinheiro A. C., Cerqueira M. A., Rocha C. M., Avides M. C., Quintas M. A. and Vicente A. A. 2011. Physicochemical characterization of chitosanbased edible films incorporating bioactive compounds of different molecular weight. Journal of Food Engineering, 106:111-118.

Bourtoom T., 2008. Edible films and coatings: characteristics and properties. International Food Research Journal 15 237-248

Chakraborty, P. M., Lemeguer and Jelen, P. 1986. Coconut proteins isolate by ultrafiltration. Food Engineering Application, 2: 308-315.

Fundo J. F., Quintas M. A. and Silva C. L. 2008. Influence of film forming solutions on properties of chitosan/glycerol films. Centro de Biotecnologia e Química Fin, 21:323327.

Galgano, F., Condelli, N. F., Fava, T., Bianco, G., Perretti and Caruso, M. C. 2015. Biodegradable packaging and edible coating for fresh-cut fruits and vegetables. Italian Journal of Food Science, vol. 27.

Han, J. H. and Floros, J. D. 1997. Casting antimicrobial packaging films and measuring their physical properties and antimicrobial activity. Journal of Plastic Film and Sheeting, 13(4):287-298 .

Igor, B., Arno, C. A. and Maykel, V. 2007. Structural effects on the permeability of whey protein films in an aqueous environment. Food Hydrocolloids, 21: 889-895.

Javier, O., Idoya, F., Mauricio, M. and Uan, I. M. 2007. Stability of the mechanical properties of edible films based on whey protein isolate during storage at different relative humidity. Food Hydrocolloids, 23:125-131.

Kadam, D.M., Thunga, M., Wang, S.,
Kessler, M. R., Grewell, D., Lamsal, B. and $\mathrm{Yu}, \mathrm{C}$. 2013. Preparation and characterization of whey protein isolate films reinforced with porous silica coated titania nanoparticles. Journal of Food Engineering, 117:133-140.

Kilara A and Vaghela M N (2004)Whey proteins. In: R.Y. Yada (Ed.), Proteins in Food Processing, Woodhead Publishing Ltd, Cambridge, pp 72-100

Leceta I., Guerrero P. and Caba K. D. 2013. Functional properties of chitosan based films. Carbohydrate Polymers, 93:339346.

Mahamadou, E. G., Shi-ying, X. and Wang, Z. 2007. Whey protein isolate-based edible films as affected by protein concentration, glycerol ratio and pullulan addition in film formation. Journal of Food Engineering, 83:521530.

Majid, J. 2009. Biodegradable whey protein edible films as a new biomaterials for food and drug packaging. Iranian Journal of Pharmaceutical Sciences, 5(3): 129-134.

Markus, S. 2013. Properties of cast films made from different ratios of whey protein isolate, hydrolysed whey protein isolate and glycerol. Materials, 6:32543269.

Oscar, L., Ramos, A., Sara, I., Silva, A., Jose, C., Soares, A., Joao, C., Fernandes, A., Fatimapoças, A; Manuela, E., Pintado, A. and Xavier, M. 2012. Features and performance of edible films, obtained from whey protein isolate formulated with antimicrobial compounds. Food Research International, 45: 351-361.

Ramos O. L., Reinas I., Silva S. I., Fernandes J. C., Cerqueira M. A., Pereira R. N., Vicente A. A., Pocas M. F., Pintado M. E., and Malcata F. X. 2013. Effect of whey protein purity and glycerol content upon physical properties of edible films manufactured there from. 
Food Hydrocolloids. 30:110-122.

Roy, S., Gennadios, A., Weller, C. and Testin, R. 2000. Water vapor transport parameters of a cast wheat gluten film. Biological Systems Engineering: Papers and Publications, 199: 43-50.

Singh T. P., Chatli M. and Sahoo J. 2015. Development of chitosan based edible films: process optimization using response surface methodology. Journal of Food Science and Technology, 52(5):2530-2543.

Sobral P. J., Menegalli F. C., Hubinguer M. D. and Roques M. A. 2001. Mechanical, water vapour barrier and thermal properties of gelatin based edible films. Food Hydrocolloids, 15:423.

Suzana, R. B., Vesna, L., Mladen, B., Tomislav, B., Damir, J. and Marija. 1997. Thermal gelation of whey protein at different $\mathrm{pH}$ values. Faculty of food technology and biotechnology, pierottijeva 6 , zagreb, Croatia.

Theeranun, J. and Krochta, J. M. 2010.Edible Packaging Materials. Annual Review of Food Science and Technology,
Department of Food Science and Technology, University of California, Davis, California. 9:5616-8686.

Wagh Y. R., Pushpadass H. A., Magdaline E., SurendraNath B. 2014. Preparation and characterization of milk protein films and their application for packaging of Cheddar cheese. Journal of Food Science Technology. 51(12):3767-3775. Wang, L., Mark, A. and Joe, P.K. 2010b. Physical assessment of composite biodegradable films manufactured using whey protein isolate, gelatin and sodium alginate. Journal of Food Engineering, 96:199-207.

Yan Q, Hou H, Guo P, Dong H. 2012.Effect of extrusion and glycerol content on properties of oxidized and acetylated corn starch-based films. Carbohydrate Polymers, 87:707-712.

Zolfi, M., Faramarz, K., Mohammad, M. and Maryam, H. 2014. The improvement of characteristics of biodegradable films made from kefiran-whey protein by nanoparticle incorporation. Carbohydrate Polymers, 109: 118-125.

\section{How to cite this article:}

Shingala Abhishaben, M., V.K. Chandegara, Bhukya Jithender and Singala Pankajkumar, M. 2019. Whey Protein Isolate based Biodegradable Food Packaging Film as affected by Protein to Glycerol Ratio, Ph and Sonication Amplitude. Int.J.Curr.Microbiol.App.Sci. 8(03): 895-909. doi: https://doi.org/10.20546/ijcmas.2019.803.107 